\title{
Neo-Industrial Structural Shifts in Sustainable Development Methodology
}

\author{
Sergey Zhironkin ${ }^{1,2}$, Olga Aleshina ${ }^{2}$, Vladimir Gorev ${ }^{2}$ Yuriy Gunyakov², and Olga \\ Zhironkina $^{3, *}$ \\ ${ }^{1}$ T.F. Gorbachev Kuzbass State Technical University, 650000 Kemerovo, 28 Vesennya st., \\ Kemerovo, Russia \\ ${ }^{2}$ Siberian Federal University, 660075 Lida Prushinskaya St. 2, Krasnoyarsk, Russia \\ ${ }^{3}$ Plekhanov Russian University of Economics, Kemerovo branch, 650992, pr. Kuznetskiy, 39, \\ Kemerovo, Russia
}

\begin{abstract}
Human economic activity, production and use of goods and services take place in the framework of a close exchange of materials and energy with the environment. Entering into relationship with the natural environment, industrial enterprises form a dynamic ecological-andeconomic system, which is a combination of two jointly functioning subsystems: ecological and economic. The main feature of the ecologicaland-economic system is the balance, proportionality, balance of its natural and industrial subsystems. In this regard, a necessary condition for the transition of economy to sustainable development should be the reduction of the environmental capacity of production through the introduction of a new business philosophy, which is based on greening processes. Environmental activities, as one of the components of a balanced development, are becoming more and more economically viable, allowing enterprises to use the various direct and indirect benefits and profits associated with it, preventing negative environmental impacts. Of particular importance is the expansion of the economic basis of environmental activities in the conditions of modern structural changes in the economy, radically changing the proportions of consumption of natural and intellectual resources. Today, such structural changes are neo-industrial in nature, marking a new stage in the development of global industry, with increasing digitalization of production and a drastic reduction in natural resource consumption as well as harmful emissions cut.
\end{abstract}

\section{Introduction}

There are several definitions of sustainable development. The earliest and perhaps the least successful of them is the definition contained in the report of the Brundtland Commission in 1997 , according to which sustainable development is the progress that provides an ecological balance between present and future generations [1]. It means that the livelihoods of the current generation do not impose an additional environmental burden on the generation that is replacing it. The disadvantages of this definition are obvious: firstly, it is too eco-friendly,

\footnotetext{
${ }^{*}$ Corresponding author: o-zhironkina@mail.ru
} 
since the ecological balance is by no means the only balance that should be maintained in the course of sustainable development; secondly, a comprehensive, not only ecological, balance should be maintained not only between generations, but within these generations as well, which is of no less, if not more, significance for the sustainability of development. One cannot count on sustainable development if there is a conflict of interests between the social and property strata of the population within the country or between the periphery and the center in the world social system [2-4]. Moreover, one can hardly agree with the opinion that it is environmental sustainability that should be the basis of the development strategy of any country, especially if it is designed for the long term.

The concept of "sustainable development of human settlements", given in 1996 at the Istanbul Conference on Urban Development, means "stimulating local economic development (expanding the economic potential of a territory, regulating demographic processes, creating jobs, business infrastructure, improving the competitiveness of enterprises, etc.) based on social and environmental impact assessments; preventing further environmental degradation, overcoming unhealthy living conditions for people" [5].

Thus, there is an environmentally oriented approach to defining sustainable development, which underlines the economic foundations of resource use and production - technologically driven structural shifts, as well as neo-industrial structural transformations of the economy.

\section{Materials and Methods}

Methodologically, the analysis of the role of structural changes in ensuring sustainable development implies the following tasks [6-8]:

1. To systematize the theoretical foundations of the formation of sustainable development of national industries as ecological-economic systems.

2. To develop model options and propose a criterion for choosing the optimal environmental and economic development for industry.

3. To develop and justify an algorithm for evaluating the effectiveness of greening production.

4. To identify the socio-economic trends in the development of industry and justify promising areas of its digitalization.

5. To develop a mechanism for the formation and development of environmental management systems as a functional basis for sustainable development.

6. To develop a methodological basis for optimizing the management of industrial and consumer waste at the level of industrial enterprises.

7. To develop and justify a methodology for assessing the effectiveness of the use of secondary resources in industry.

In our opinion, the term "neo-industrial development" reflects to the essence of the problem in a much greater extent, since it focuses attention not only on the time matter of phenomena, but also on the need for a rational, if not optimal, combination of economic, social, demographic and ecological processes in the interests of multiplying physical, spiritual and mental forces of humanity.

Neo-industrialization is a form of innovative development of the economies of the leading countries in the late 20 th - early 21 st centuries, with the following characteristics: reduction in basic raw materials and growth in the processing industries, industry-wide convergence of raw materials processing, robotization and digitalization of production, transformation of scientific research into an independent sector of economy, informatization and increasing the technological level of the service sector [9-10]. All this manifested in a significant increase in value added, productivity and social welfare growth, consumption of goods.

Unlike common technology-oriented approaches to the study of neo-industrialization of the economy, its quintessence is defined by the authors as systemic structural changes in 
economic relations and productive forces influenced by scientific and technological progress, property transformation in the development of public-and-private partnerships, the development of networked business organization, vertical scientific and industrial integration, as well as targeted structural policy of the state [11-13].

The definition of a structural shift includes qualitative changes in proportions and relationships in homogeneous subsystems and segments of the economy (new properties, functions of elements, their relationships), the genesis of which is associated with an imbalance in the distribution of resources between structural elements, which, in turn, causes their uneven and disproportionate dynamics. Such dynamic imbalances are manifested at the level of individual households, entrepreneurial firms, regional and sectoral structures, in the national and world economy, causing structural shifts in the corresponding levels. At the same time, at the highest levels, structural shifts aggregate radical transformations of the lower levels, cumulatively connecting the new proportions of economic resources distribution among the elements of the economic system. The manifestation of the object of structural changes in economic practice occurs in the process of establishing certain interelement proportions in the system of the national economy (macro, meso-economic).

In the modern multi-structured economy, the subjects of structural changes are the state, large corporations, households that form consumer demand and savings, as well as the institutionalized innovation infrastructure (venture funds, technology parks, network hightech companies).

The aggregation nature of structural shifts, consolidating certain quantitative changes in various types of economic structure into a qualitative jump (positive or negative), follows the general law of elevation and internationalization of needs, which induces a new quality of production. The qualitative jump is the quintessence of a structural shift and means development of economic relations, modification of their forms, formation of new subjects. Thus, the economy creates conditions for the transfer of innovations, the redistribution of production factors and the increase in the efficiency of their use, which are integral functions of structural shifts [14-15]. These functions are summarized in the nature of structural changes (negative or positive), which determines the quality of economic development, sets the upward or downward wave of economic dynamics. These dynamics, subsequently, defines the conditions of sustainable development - technologies, investments, culture [16$18]$.

\section{Results and Discussion}

The nexus of the neo-industrial structural shift and sustainable development belongs to expansion of a type of industry in which the use of returnable raw materials and digital methods for optimizing resource use are dominative. Meaning all the above, the following neo-industrial criteria for sustainable development should be considered:

- provision of renewable resources, at least, should not decrease, and stocks of so-called nonrenewable resources should not only be spent more economically, but also replenished by discovering and developing new energy sources and new types of materials, i.e. turn into virtually inexhaustible resources;

- average and marginal resource intensity of the economy should not increase, i.e. the ratio of the cost of natural resources to the product growth should be at least stable;

- average and marginal ecological capacity of the economy, i.e. the ratio of waste production, including emissions of environmentally harmful substances, to product growth, at least, should not increase;

- the level of labor productivity and the share of intensive factors in the growth of the product, at least, should not decrease 
- the level of income (net product) per capita, at least, should not decrease, and the degree of unevenness in the distribution of income (net product) per capita, at least, should not increase.

If we are talking about environmentally sustainable development, then in this case two conditions should be observed, at the entrance to the economy and at the exit from it, that the resource intensity and environmental intensity of the economy should at least not increase. However, in this case, some reservations are needed.

First, by nature intensiveness we mean the unit costs of natural resources per capita or per unit of final product.

Secondly, the environmental capacity refers to the specific waste of production and consumption, as well as emissions of environmentally pollutants per capita, a unit of the final product and per unit cost of natural resources.

Thirdly, the application of these factors will only make sense when not only the actual capacity of the natural environment, but also the actual limits of its pollution are scientifically proven.

Fourthly, if the new types of materials and new sources of energy are explored and mastered, and the resource base is thereby expanded, then the first condition for environmentally sustainable development must be properly adjusted.

Fifthly, if the expenditures of natural resources are not expressed in proportional growth of waste and emissions, then the second condition of environmentally sustainable development should be corrected.

In other words, with the current state of theory and practice of economic and environmental development, we still do not know the exact quantitative links between economy and ecology, and therefore some caution is needed in formulating the conditions under which ecologically sustainable development of the economy becomes possible.

Indicators of sustainable development should be the parameter of reducing the environmental intensity of the economy and the structural indicator reflecting the decrease in the share of products of the natural resource-producing sectors. The indicator of nature intensity characterizes the type and level of ecological and economic development and depends on the efficiency of using natural resources at all stages of the life cycle of the goods produced.

The economic and practical sense of the integration of the categories of neo-industrial structural shifts and sustainable development means the development of environmental management in modern industry.

At present, at various levels of management, some measures are being taken to implement the principles of sustainable development and ensure environmental safety of production through, first of all, greening the economy, which corresponds to the third condition. Greening is the integration of social, ecological and economic processes based on the adoption of interrelated economic, technological, political and social decisions that contribute to the effective achievement of environmental goals and objectives in any ecological-and-economic system.

Enterprises that develop their activities in the environmental field in accordance with above-spoken conditions adhere to the strategies of "active environmental management" and "sustainable development", following which involves a gradual approaching of resource cycles to closed circulation of substances in nature. Environmental management must be an initiative activity of economic entities, aimed at the formation and implementation of environmental policy and management of environmental aspects of activities within the framework of the general system of administrative management. Environmental management is a key dominant of sustainable development and at the same time one of the highest priorities of industrial activity and entrepreneurship. The most important direction of implementation of environmental management is the standardization of environmental activities of enterprises. 
Depending on the specifics of the goals and objectives, the resources required and the scope of work, as well as the possibilities for demonstrating and putting results to practical use, three strategies are possible for industrial enterprises to use the ISO 14000 series of standards in environmental management development:

1. Application of a standard by an enterprise in order to certify the creation of an environmental management system by a third party, i.e. use of performance results to obtain formal benefits related to certification of the environmental management system.

2. Application of the standard in order to create an effective environmental management system in the enterprise, i.e. open demonstration of the consistent improvement of the environmental management system as a whole (policy, planning, organization, audit, documentation) and the results of the activities on the example of some of the most significant and winning environmental goals and objectives.

3. The application of the standard in order to create and use the environmental management system as a tool that allows an enterprise to achieve and demonstrate a consistent improvement in all environmental aspects of activity where this is practically achievable, i.e. use of environmental management system to improve the economic efficiency of production activities.

\section{Conclusions}

Thus, the implementation of neo-industrial structural transformations of the economy is increasingly taking the form of shifts in the structure of the reproductive system, with a characteristic radical reduction in resource consumption, the transition to lean production and recycling technologies. In accordance with this, the formation of macroeconomic (reproduction) and microeconomic (environmental management) conditions of the neoindustrial structural shift in the economy should be a crucial step towards sustainable development.

\section{References}

1. J. Manns, Town \& Country Planning, 8, 337-340 (2010)

2. S. Zhironkin, D. Khloptsov, N. Skrylnikova, I. Petinenko, O. Zhironkina, E3S Web Conf., 41, 04010 (2018)

3. O. Kalenov, S. Kukushkin, E3S Web of Conf., 41, 04025 (2018)

4. O. Kalenov, E. Shavina, E3S Web of Conf., 41, 04054 (2018)

5. T.V. Kiseleva, V.G. Mikhailov, Economics and Innovation Management, 4, 70-78 (2018) DOI:10.26730/2587-5574-2018-4-70-78

6. E.A. Gasanov, T.S. Boyko, N.S. Frolova, Economics and Innovation Management, 3, 48 (2018) DOI: 10.26730/2587-5574-2018-3-4-8

7. S. Zhironkin, M. Gasanov, G. Barysheva, E. Gasanov, O. Zhironkina, G. Kayachev, E3S Web Conf., 21, 04002 (2017)

8. M.A. Gasanov, K.A. Kolotov, K.A. Demidenko, E.A. Podgornaya, O.V. Kadnikova, IOP Conf. Ser.: Earth Environ. Sci., 50:1, 012025 (2017)

9. M. Cehlár, L. Mihok, Theoretical and Empirical Researches in Urban Management 8:4, 60-72 (2013)

10. M. Cehlár, J. Janočko, Z. Šimková, T. Pavlik, M. Tyulenev, S. Zhironkin, M. Gasanov, Resources, 8:1, 21 (2019) 
11. E.A. Gasanov, M.A. Gasanov, Economics and Innovation Management, 1, 30-38 (2017) DOI: $10.26730 / 2587-5574-2017-1-30-38$

12. V. Osipov, T. Skryl, N. Nevskaya, E. Shavina, International Business Management, 10:9, 1649-1657 (2016)

13. E. Dotsenko, N. Ezdina, S. Mudrova, E3S Web Conf., 41, 04050 (2018)

14. M.V. Rylnikova, D.N. Radchenko, Gorn. Zhurnal, 12, 122-130 (2014)

15. K.N. Trubetskoy, Y.P. Galchenko, J. Min. Sci., 51:2, 407 (2015)

16. Sustainable Economic Development. Resources, Environment and Institutions (Massachusetts: Academic Press, 2015)

17. M. Bussire, J. Imbs, R. Kollmann, R. Rancire, Am. Econ. J. Mac., 5, 75 (2013)

18. E. Dotsenko, N. Ezdina, E3S Web of Conf., 15, 04012 (2017) 